\title{
RETURN OF THE CULTURAL OBJECTS UNDER INTERNATIONAL LAW, EUROPEAN UNION LAW, AND LITHUANIAN LAW
}

\author{
DEVOLUÇÄO DOS OBJETOS CULTURAIS DE ACORDO COM A LEI \\ INTERNACIONAL, A LEI DA UNIÄO EUROPEIA E A LEI DA LITUÂNIA
}

Pavelas Ravlusevicius ${ }^{\mathrm{I}}$ I'Mykolas Romeris University, Vilnius,
Lituânia.

DOI: http://dx.doi.org/10.20912/rdc.v16i40.589

Autor convidado

\begin{abstract}
The article examines the legal problems associated with the return of cultural objects in International, European Union, and Lithuanian Laws, as well as the extraterritorial application of mandatory norms. Particular importance is given to the influence of the UNIDROIT Convention on Stolen or Illegally Exported Cultural Objects and the Directive 2014/60/EC on the return of cultural objects unlawfully removed from the territory of a Member State. Attention is paid to the correlation of civil law doctrines with the protection of the owner's rights and the bona fide purchaser of a cultural object on the one hand, and International and European Laws about the return to the owner and compensation to the owner of a cultural object on the other hand, because Lithuanian legislation and case law do not apply the vindication doctrine to protect owner's rights of cultural objects and thus differs from the traditional approach to solving the problems of returning cultural objects within the civil law framework. The article deals with the related problems of recognition of the owner's rights and changes in the evidence presumptions. The issue of restoring the owner's rights to illegally confiscated cultural objects during the existence of the USSR was decided in the practice of the Constitutional Court of the Republic of Lithuania. Courts of general jurisdiction considered claims for the return of cultural objects belonging to foreign entities - the Federal Republic of Germany and the Prussian Cultural Heritage Foundation. Particular importance was the question of the application of International and European Laws in judicial practice. According to the results of the study of the practice of the Republic of Lithuania, it is proposed to regard the return of cultural objects as an independent way of protecting the owner's rights, which makes secondary the bona fide purchaser doctrine in relation of a cultural object.
\end{abstract}

Keywords: Cultural. International. Law. 
Resumo: $\mathrm{O}$ artigo examina os problemas jurídicos associados à devolução de objetos culturais nas Leis Internacional, da União Europeia e da Lituânia, bem como a aplicação extraterritorial de normas obrigatórias. É dada especial importância à influência da Convenção UNIDROIT sobre bens culturais roubados ou exportados ilegalmente e da Diretiva 2014/60 / CE relativa à devoluçáo de bens culturais retirados ilegalmente do território de um Estado-Membro. É dada atençáo à correlação das doutrinas do direito civil com a proteçấo dos direitos do proprietário e do comprador genuíno de um bem cultural, por um lado, e às Leis internacionais e europeias sobre o retorno ao proprietário e compensaçáo ao proprietário de um objeto cultural objeto, por outro lado, porque a legislação e a jurisprudência da Lituânia não aplicam a doutrina de reivindicaçáo para proteger os direitos do proprietário de bens culturais e, portanto, difere $\mathrm{da}$ abordagem tradicional para resolver os problemas de devoluçáo de bens culturais no quadro do direito civil. O artigo trata dos problemas relacionados de reconhecimento dos direitos do proprietário e mudanças nas presunçóes de evidência. A questão de restaurar os direitos do proprietário a bens culturais ilegalmente confiscados durante a existência da URSS foi decidida na prática do Tribunal Constitucional da República da Lituânia. Os tribunais de jurisdição geral consideraram os pedidos de devolução de bens culturais pertencentes a entidades estrangeiras - a República Federal da Alemanha e a Fundação do Património Cultural da Prússia. Particular importância foi a questão da aplicação do Direito Internacional e Europeu na prática judicial. De acordo com os resultados do estudo da prática da República da Lituânia, propóe-se considerar a devolução de bens culturais como uma forma independente de proteger os direitos do proprietário, o que torna secundária a doutrina do comprador genuíno em relaçáo a um bem cultural .

Palavras-chave: Cultural. Internacional. Lei.

\section{Relationship between National Law, International and European Union Laws}

Republic of Lithuania's legal system is influenced by international regulation in the field of cultural cooperation. Norms about the return of cultural objects are based on the International and European Laws, so that the relationship of Lithuanian Law with International and European Laws acquires not only doctrinal but also practical significance for legislative and judicial practice.

Article 138 part 2 of the Constitution of the Republic of Lithuania ${ }^{1}$ provides for international treaties ratified by the parliament are an integral part of the Lithuanian legal system. In the practice of international relations, not all treaties are subject to ratification. It can be argued that most of the concluded international treaties are not subject to ratification for entry

1 Bulletin of the Republic of Lithuania, $1992 \mathrm{Nr}$. 33-1014. 
nto force. The Constitutional Court, ${ }^{2}$ by interpreting this norm of the Constitution, concluded that the agreement, subject to ratification, has got the force of law in Lithuanian Law. For international treaties that do not require ratification to enter into force, the Constitutional Court did not provide the force of law in Lithuania.

This interpretation has caused a lot of points of view on the issue of international treaties in Lithuanian Law, which eventually led to the reform of the 1991 Law on International Treaties, as well as the Law on International Treaties became after the interpretation of the Constitutional Court is not enough precisely defined. ${ }^{3}$ In addition, it should be noted that the Republic of Lithuania is a state party to the UNIDROIT Convention on Stolen or Illegally Exported Cultural Objects (hereinafter referred to as the UNIDROIT Convention), which was ratified by the Parliament of Lithuania on January $14^{\text {th }}, 1997$. The UNIDROIT Convention came into force for Lithuania on July $1^{\text {st }} 1998 .{ }^{4}$ Therefore, the definition of the effect of international treaties in the national legal system remained an important issue. Subsequently, the 1999 Law on International Treaties was adopted, ${ }^{5}$ proceeded from the positions of the Convention of Vienna on the Law of Treaties of May 23 ${ }^{\text {rd }}, 1969$, providing for the obligation to comply with international treaties (pacta sunt servanda), which are concluded by states as subjects of International Law that a State cannot invoke the provisions of its internal law as an excuse for its failure to comply with an international treaty.

The relationship between International Law and National Law is regulated by separate articles of the Law on International Treaties of the Republic of Lithuania. According to Article 11 of Part 1 of this Law, international treaties of the Republic of Lithuania that have come into force, as well as the temporarily applied international treaties, are subject to implementation in the Republic of Lithuania. The interpretation of Article 11 of the Law on provisionally executable International Treaties has become extremely relevant since international treaties that have not entered into force are subject to application in national law.

It should be noted that provisionally applied international treaties have certain specificity in International Law. The Convention of Vienna on the Law of Treaties regulates in Article 25 the provisional application of treaties. A treaty or part of a treaty shall be applied temporarily until the treaty comes into force if this is provided for by the treaty itself or the states participating in the negotiations have agreed to do so in some other way.

The question arises is to what extent the temporary application of international treaties that are not considered to be treaties that have entered into force between the parties, such as whether the treaty, designed as an agreement in the field of cultural cooperation, is valid between the Republic of Lithuania and the Federal Republic of Germany, ${ }^{6}$ executed at government level on July $21^{\text {st }}, 1993$. On the initiative of the German side, it was proposed to temporarily apply the agreement in German-Lithuanian relations. The Lithuanian side agreed with the German side's suggestion. The provisional application was negotiated based on the parties' "notes verbales". The

2 Resolution of the Constitutional Court of the Republic of Lithuania on the Compliance with the Constitution of the Republic of Lithuania. Article 7 h. 4 and Article 12 of the Law on International Treaties of the Republic of Lithuania, Vilnius, October 17 $7^{\text {th }}, 1995$.

3 Bulletin of the Republic of Lithuania, $1991 \mathrm{Nr}$. 16-415.

4 Bulletin of the Republic of Lithuania, 1997 Nr . 8-139.

5 Bulletin of the Republic of Lithuania, $1999 \mathrm{Nr}$. 60-1948.

6 Bulletin of the Republic of Lithuania, $2012 \mathrm{Nr}$. 83-4352. 
parties agreed on August $5^{\text {th }}, 1994$ to apply the agreement temporarily, guided by the provisions of the national law of each of the parties. For both parties, this agreement has not come into force. This is precisely the peculiarity of the provisionally applied treaty. They bind the parties before they enter into force.

In International Law, treaties temporarily applied cause criticism, since in this way the constitutional requirements necessary for the entry into force of the treaty may not be observed. The main principle of the obligation of international treaties that have not entered into force is doubtful, but this type of treaty has become widespread in international practice. ${ }^{7}$

Article 16 of this agreement on cultural cooperation between the Republic of Lithuania and the Federal Republic of Germany states that the parties agree that the missing or illegally exported cultural property located on their territory should be returned to the owners or their heirs.

Republic of Lithuania's legal acts that regulate the return of cultural objects contain norms on the application of international legal acts, which, as a rule, provide for the prerogative of international regulation in comparison with national regulation. Article 7 of the Museum Law provides for the provision according to which, if international agreements of the Republic of Lithuania provide for other rules than the law, then the rules of the international agreement shall be applied. ${ }^{8}$ Besides Article 17 of the Law on the Protection of Movable Cultural Objects introduced a similar legal norm concerning third countries not members of the European Union, according to which, if international treaties or conventions of the Republic of Lithuania establish rules other than those provided for in legal acts regulating the protection of movable cultural objects, the rules of international treaties of the Republic of Lithuania should be applied.']

The relationship between European Union Law and National Law is regulated by the Constitutional Act on the membership of the Republic of Lithuania in the European Union, ${ }^{10}$ which in Part 2 provides that the legal norms of the European Union are an integral part of Republic of Lithuania's legal system. In the event of a conflict of European Union legal norms with national laws and other Republic of Lithuania's legal acts, European Union Law shall prevail over national law.

The Constitutional Court, by interpreting the norms of the Constitutional Act, limited the rule of law of the European Union in the event of a conflict with the norms of the Constitution of the Republic of Lithuania, recognizes the primacy of EU Law in the Lithuanian legal system. However, make reservations about the Constitution of the Republic of Lithuania, which according to the court legitimizes a member state in the European Union and therefore European Union Law cannot contradict it. ${ }^{11}$

7 Rene Lepeber, Treaties Provisional Application in: The Max Planck Encyclopedia of Public International Law, Volume X, Oxford University Press, 2012, p. 4.

8 Bulletin of the Republic of Lithuania, 1995 Nr . 53-1292. Nr. XIII-1315, 2018-06-27, TAR publication 201806-30, ik 2018-10967.

9 Bulletin of the Republic of Lithuania, 1996 Nr . 10-178, 2016-11-03, Nr. XII-2726, publication, paskelbta TAR 2016-11-16, ik 2016-26896.

10 Bulletin of the Republic of Lithuania, 2004 Nr . 111-4123.

11 2006-03-14 Ruling of the Constitutional Court of the Republic of Lithuania, case Nr . 17 / 02-24 / 02-06 / 03-22 / 04. 
The resolution of conflicts between national and European Union Law may be relevant in the case of the implementation of Directive 2014/60/EU on the return of cultural objects unlawfully removed from the territory of a Member State. A potential conflict is possible when interpreting state ownership of cultural objects and requiring their return to other owners. The problem of the constitutionality of the Directive 2014/60/EU provisions cannot be ruled out. In the case, the Law on the Protection of Movable Cultural Objects, ${ }^{12}$ as well as the Resolution of the Government of the Republic of Lithuania on August 31 st, 2004 on approving the rules for the Return of Illegally Exported Cultural Objects from the Territory of a Member State of the European Union, gave effect to the Directive 2014/60/EU in the Republic of Lithuanian legal system. ${ }^{13}$

\section{Features of the UNIDROIT Convention on Stolen or Illegally Exported Cultural Objects}

\subsection{Return of stolen cultural objects}

The legal provisions of the UNIDROIT Convention on Stolen or Illegally Exported Cultural Objects represent a compromise solution between the protection of owner's rights and the bona fide purchaser of the stolen cultural object. ${ }^{14}$

Article 3 part 1 of the UNIDROIT Convention provides for the regulation that the owner of a stolen cultural object must return it. Article 3 Part 2 of the UNIDROIT Convention defines the concept of a stolen cultural object. In this case, a cultural object originating from unauthorized excavations or legally excavated but unlawfully removed first is considered as stolen first. Another aspect of the recognition of the fact of abduction is based on the comparison of theft under the criminal law of that country. In practice, there are cases when objects were stolen, but no one initiated criminal cases. Therefore, theft will not imply criminal prosecution in any way.

In addition, Article 9 part 1 of the UNIDROIT Convention allows a contracting state to apply any more favourable rules for the return of cultural objects that have been stolen or illegally exported. For legal systems that do not recognize the bona fides acquisition of stolen items, this requirement is not special. It should be noted that the regulation of the Convention transforms the idea of good faith in the acquisition of property. The UNIDROIT Convention does not deliberately use the definition of good faith in acquisition to avoid conflicts with national systems of law that would have to implement this Convention and apply its norms in practice. The difference in ideas about the good faith in the acquisition is obvious and Convention's drafters decided not to deepen it and not complicate the way of establishing a universal category for the return of cultural objects in civil law.

\subsection{Return of illegally exported cultural objects}

The return of illegally exported cultural objects is peculiarly regulated in the UNIDROIT Convention. A simplification is envisaged that once an item exported will be later recognized

12 Bulletin of the Republic of Lithuania, $1996 \mathrm{Nr}$. 14-352.

13 Bulletin of the Republic of Lithuania, $2004 \mathrm{Nr}$. 135-4900.

14 Christa Roodt, Private International Law, Art and Cultural Heritage, Edward Elgar Publishing, 2015, p. 71. 
as illegally exported in other jurisdictions. Article 5 of the Convention grants the right to return illegally exported cultural objects. This takes into account the terms of the Convention, which must be met to exercise the right to return. The legal meaning of the wording "illegally exported from the territory of the state" - the plaintiff covers the norms at the level of law and administrative regulations on the export of cultural objects. The illegality of export is often interpreted in a variety of ways. ${ }^{15}$

State institutions regulate the procedure for the export of cultural objects that proceed from their interests. The legal norms adopted by them are aimed at the return of cultural objects, which makes it possible to potentially qualify any export of cultural objects as illegal. This is also where the norms of public and private law collide.

Export procedures are governed by public law, and the sale of the cultural object itself is private and governed by private law. A situation is possible when an object is legally sold that is not subject to export, but the new owner still took it out. The owner himself, wanting to profitably sell the cultural object, strives to transfer it abroad and sell it there. It must be admitted that cultural objects are stolen more often with their subsequent export abroad.

The UNIDROIT Convention provides for a regulatory concept under which the requirement to return the illegal export of cultural objects is implemented. The legal solution of the Convention is non-traditional and special for legal systems based on the recognition of the rights of the owner. Currently, the European Union Law is practicing a similar legal regulation.

\subsection{Compensation}

Articles 4 and 6 of the UNIDROIT Convention provides for the institution of fair and reasonable compensation, especially from the point of view of the traditional civil law, which is applied to the owner of a stolen cultural object, as well as the owner of an illegally exported cultural object who must return it. This institution is a kind of compensation or a kind of replacement for the doctrine of the bona fide acquisition in traditional civil law. The main condition for payment is that the owner of the stolen or illegally exported cultural object did not know or reasonably should not have known (i.e., assumed) that the object could have been stolen or illegally exported. In civil law terms, the owner should be careful enough when purchasing a thing. ${ }^{16}$

The UNIDROIT Convention also modifies the presumption of evidence rules. The owner himself is obliged to prove that when purchasing a cultural object, he paid attention carefully, as well as providing documents, such as documents that include an export certificate. Traditional civil law does the opposite, by requiring the owner himself to provide evidence of the owner's

15 Sophie Vigneron, Protecting Cultural Objects: Enforcing the Illicit Export of Foreign Cultural Objects, In: Valentina Vadi, Hildegard EGS Schneider, Art, Cultural Heritage and the Market, Springer, 2013, p. 117.

16 Michael Anton: Handbuch Kulturgüterschutz: llegaler Kulturgüterverkehr, De Gruyter Verlag, 2010, S. 255. 
imprudence or gross negligence. In the case of a good faith acquisition, traditional civil law recognizes the owner as having lost his property right.

There is no doubt that the legal guarantees of the owner under the UNIDROIT Convention are more significant when compared with Lithuanian domestic jurisdictions in civil cases. The owner will not become the owner anyway. He can defend his interests within the framework of the right to compensation. Thus, the Convention differs from national legal systems. The Convention requires the owner evidence that he was such at the time of the theft of the cultural object, the very fact of theft or illegal excavation, as well as the illegal export of the cultural object.

The usual method of traditional civil law, in addition to good faith acquisition doctrine, is the introduction of certain periods of acquisitive prescription, as well as periods of limitation of actions. The practice of applying this article of the convention to the due diligence requirements makes it impossible for owners to claim compensation. ${ }^{17}$

The purpose of the UNIDROIT Convention is to facilitate the return of a stolen cultural object. Article 9 of the Convention provides for the possibility for the Member State to apply any more favorable rules for the return of a cultural object, stolen or illegally exported. It should be noted that countries that do not recognize the bona fide acquisition of a stolen cultural object are not required to implement Articles 4 and 6 of the Convention since under Article 9 when such rules are more favorable rules than domestic jurisdiction. As a result, the cultural object is subject to return without payment of any compensation.

The amount of fair and reasonable compensation is determined taking into account all the characteristics of a particular case. This was the main idea of the norms of the convention, which did not purport to determine the amount of compensation itself because unambiguous counting is not possible.

The owner has the right to retain the item to be returned until he receives compensation. Thus, the return of the thing is made dependent on the receipt of compensation, which must meet the criteria of fairness and reasonableness.

The concept of fair and reasonable compensation usually does not coincide with the criterion of the market price of a thing, but it does not mean the payment of a symbolic sum either. From the point of view of the good faith acquisition doctrine, the owner's expenses for the acquisition and maintenance of the thing are subject to compensation. This usually covers restoration costs. It should be borne in mind that the costs must be justified, and the condition of the thing should not deteriorate from this.

It should be noted that compensation is paid by the state demanding the return of a stolen or illegally exported cultural object. A conflict of interest arises if the cultural object belonged to a private person who himself is not averse to declaring a demand for its return. The UNIDROIT Convention does not prohibit such a requirement by a private person.

From the point of view of traditional civil law, there is a contradiction with the norms of the UNIDROIT Convention, which is expressed in the fact that a bona fide purchaser is obliged to return the cultural object, and the injured owner is obliged to pay compensation. It seems

17 Astrid Müller - Katzenburg, Internationale Standards im Kulturgüterverkehr und ihre Bedeutung für das Sach - und Kollisionsrecht, Dunker Humblot Berlin, S. 103. 
that these problems are far-fetched at a theoretical level and have no practical basis. The fact is that practical cases prove the viability of the norms of the Convention. Since the owner of the cultural object needs to get it back, and the owner, on the contrary, cannot return it. As a rule, an owner who is not able to prove his discretion, therefore usually cannot claim compensation payments. The norms of the Convention state the peculiarities of the legal protection of cultural objects, while traditional civil law is based on the postulates of property law and does not reflect the specificity of protection of cultural objects. It seems that the traditional civil law protects the right of the strongest, the ones who fairly acquired a cultural object in the property.

It should be noted that the UNIDROIT Convention does not restrict the injured party's right of recourse as to the one who stole, removed, or otherwise unlawfully transferred the cultural object to the owner. The same right of recourse belongs to the owner of the object, who can claim damages.

The Convention requires discretion on the part of the owner. He must take into account all the circumstances of the acquisition of a cultural object, excluding possible doubts about the illegal origin of this object.

In the case of illegal imports, the UNIDROIT Convention does not shift the burden of proving its discretion to the owner of the property. The solution to this problem has been transferred to domestic jurisdiction. It should be noted that the most frequent cases are associated with the absence of an export certificate, which is issued under domestic law, which will be a clear indication of imprudence when acquiring a cultural object. In addition, one should take into account the peculiarities of the owner himself, who can be a specialist in the field of art history, and also be an absolute non-expert in the field of acquiring cultural objects. These criteria influence the determination of the owner's good faith. They have also been adopted by codes of ethics in cultural cooperation. Developers, which are usually museums that are interested in the return of lost cultural objects. ${ }^{18}$

\subsection{Statute of limitation}

The convention's statute of limitation is based on two distinct terms, which apply with different legal implications.

The relative limitation period begins its report from the moment when the person knew the location of the object. In this case, the plaintiff must file a claim within 3 years. The relative statute of limitation can be restored if omitted.

The absolute term begins its report from the moment the cultural object is stolen. Its duration is 50 years. States, when acceding to the convention, can extend the absolute term of the Convention to 75 years or more. This period cannot be restored.

For special types of cultural objects belonging to archaeological objects or constituting public collections, the limitation period does not apply, except for a 3-year period for notifying the plaintiff about the location of the object.

In the case of the illegal removal of an object, the same statute of limitation applies. It should be noted that the Convention itself does not provide for the use of statutes of limitation

18 V. Vadi and H. Schneider, Art, Cultural Heritage and the Market: Legal and Ethical Issues, in: Valentina Vadi, Hildegard EGS Schneider, Art, Cultural Heritage and the Market, Springer, 2013, p. 5. 
as in the case of the theft of cultural objects belonging to archaeological objects or constituting public collections.

Comparing the regulation of the statute of limitation with national law, it should be noted that the conventional solution is a kind of compromise. The fact is that the absolute limitation period of to 75 years shortens 1 and 3-year terms for notifying the plaintiff about the location of the object, which in legal practice are considered too short. This period corresponds to some extent to acquirers' interests of the lost cultural objects. In the interests of economic turnover, it is recognized at the international level as a fair decision, if a person who knows about the location of a cultural object does not take any action to return it, then he loses the right of ownership of this object. The absolute term for return expresses the interests of the states from which cultural objects disappear or can potentially disappear. ${ }^{19}$

The start of the statute of limitation record in national law is not the same. In legal systems, there are periods during which a thing can be reclaimed from any owner, regardless of the good faith of the acquisition. Art. 4.96 of the Civil Code of the Republic of Lithuania provides that a thing can be claimed from a bona fide purchaser if the thing was lost or stolen by him, as well as in cases where he lost it without his will. ${ }^{20}$ The Civil Code establishes a 3-year term from the date of loss. The interruption of this period is usually not foreseen. After the expiration of the term, the vindication of the object from the bona fide possession becomes impossible. For instance, Article 2279 of the French Civil Code considers the moment of theft of the thing, as well as its loss, as the starting point of the statute of limitations. ${ }^{21}$

United States Law is based on the concept of the so-called discovery rules when the timing begins from the moment the plaintiff finds the person who acquired the thing, and also if such a person should have been discovered. Moreover, it is taken into account whether the plaintiff could find out about the finding of the thing, whether he had such an opportunity. The statute of limitation in the United States is state-specific as there is no federal regulation. ${ }^{22}$

The Federal Republic of Germany's law is based on a subjective point, i.e. about the plaintiff's awareness of his right to claim. The limitation period is 10 or 30 years. $^{23}$

These examples highlight differences in approaches at the national level. The features of cultural objects are not taken into account by traditional civil law. ${ }^{24}$

Under the influence of the UNIDROIT Convention, special norms appeared, taking into account the specifics of the cultural object. An example of this is Swiss Law, where before the adoption of the law on the transfer of a cultural object, these relations were governed by civil

19 Thorn, Bettina, Internationaler Kulturgüterschutz nach der Unidroit - Konvention, De Gruyter Verlag, 2005, p. 123.

20 Bulletin of the Republic of Lithuania , $2000 \mathrm{Nr}$. 74-2262.

21 French Civil Code (Napoleon Code) Publisher: "Infotropic Media" (2011).

22 John Henry Merryman, "Protection" of the Cultural "Heritage"? The American Journal of Comparative Law, Vol. 38 1990, p. 515.

23 Siehr K, Kunstrecht, Verlag CH Beck, 2012, S. 93.

24 Weidner Amalie, Kulturgüter als res extra commercium im internationalen Sachenrecht, De Gruyter Verlag, 2013, S. 46. 
law. The time frame is one year from the date of knowledge of the place and the owner or 30 years from the date of loss of cultural objects. ${ }^{25}$

The Law on the Protection of Movable Cultural Objects has implemented the UNIDROIT Convention in Lithuania. Article 24 of this Law has its origins in Article 3 of the UNIDROIT Convention. Subsequently, the law was changed and the legal norms of the Convention were removed from the scope of application. This means that the Convention applies directly to Lithuanian legal system.

After joining the European Union in 2004, the Lithuanian lawmaker has sought to divide the scope of the provisions of the Convention and Directive 93/7/EEC on the return of cultural objects unlawfully removed from the territory of a Member State. The intention of the legislator was realized in 2009, therefore, the implemented norms of Directive 93/7/EEC (current Directive 2014/60/EU) remained in the current version of the Law on the Protection of Movable Cultural Objects. ${ }^{26}$

\subsection{The case Winkworth v. Christies Mason \& Woods Ltd. and others}

The outcome of this litigation determined the regulatory principles on which the UNIDROIT Convention. At the core of the case is the stealing of a collection of Japanese cultural objects from the House of Winkworth. ${ }^{27}$ The theft itself took place in England. Subsequently, the stolen collection was moved to Italy, where it was acquired by an Italian collector. The collection was then brought back to England, where it was put up for sale at the Sorby auction in London. The owner of the stolen collection has filed a vindication action against the Italian owner.

The English Court, by deciding the issue of ownership of this collection under private international law, applied Italian law at the place of acquisition of the collection. The court concluded that the right of bona fide acquisition of ownership of the collection by Italian Law was maintained, thus the Italian owner can be considered the fair owner of this collection. However, in England, there was a loss of ownership of this collection, and UK Law does not recognize ownership of the stolen property, in contrast to Italian Law. The claim of the English owner to recover his property was rejected by the English Court. This case influenced the formation of the norms of the UNIDROIT Convention, which provided for an unconditional right of reclamation in the event of theft. Until now, in the doctrine of Private Law, it is believed that the rejection of this claim is unfair concerning the person who suffered theft. UNIDROIT Convention aimed to prevent such a practice in the application of the Convention. ${ }^{28}$

Under Article 3 part 1 of the UNIDROIT Convention, Winkworth would return his collection, and the Italian owner, under Article $4 \mathrm{~h} .1$ of the Convention would have received the right to compensation if, after the contract of sale, it had been found that he behaved as a buyer with sufficient discretion.

25 Beat Schönenberger, Restitution von Kulturgut, Anspruchsgrundlagen - Restitutionshindernisse - Entwicklung, Stämpfli Verlag AG Bern - 2009, p. 73

26 Bulletin of the Republic of Lithuania , 2008 Nr. 81-3183.

27 Winkworth v Christie, Manson \& Woods Ltd., [1950] 2 Weekly Law Reports 937 (Ch. D.)

28 Siehr K. The Protection of Cultural Property: the 1995 UNIDROIT Convention and the EEC Instruments of 1992/93 Compared, RDU 1998-2 / 3, p. 675. 
The legal norms of the Convention have been also criticized. At the same time, it was mentioned that the Convention regulates the consequences and forms universal legal norms that cannot be implemented in national jurisdictions. The criticism is based on the idea of the good faith in the acquisition and non-recognition of ownership in this case. In addition, it emphasizes the peculiarity of the application of the Convention only concerning cultural objects in interstate relations, i.e. the rules of the Convention for domestic cases will not apply. ${ }^{29}$

Winkworth v. Christies Mason \& Woods Ltd. and others evidenced, how insufficient may be the possibilities of national law for the justified protection of the rights of the owner, who lost his property without his will. Today, such cases are resolved not only under the UNIDROIT Convention, but also under European Union law, which the famous result of the court case Winkworth v. Christies Mason \& Woods Ltd. simply excludes.

\section{Problems of application of legal norms of a public nature}

The legal provisions governing the procedure for export belong to the sphere of public law of a foreign state. The legal system of the state does not recognize the application on its territory the public law of a foreign state. Because the state's own public law applies on its territory. There is no conflict of laws rules for determining the application of public law. An exception is made in cases of international treaties in which these issues are regulated. The concluded international treaties and European Union legal acts regulate cases of illegal export of cultural objects in international relations between the member states. This has practical application in the requirements for the return of cultural objects that were illegally exported from the territory of one of the states. Because just fact of illegal export is enough to justify the return claims.

However, in the absence of an international agreement or special rule in the domestic legislation of a particular country, the requirement to return a cultural object may simply be rejected. This point of view is reflected in the legal tradition of civil law. The common law tradition does not recognize legal norms belonging to criminal, tax law, as well as to other norms of a public nature. It is to the norms of a public nature that the norms governing the procedure for the export of cultural objects abroad belong. In this case, there remains the last possibility of requiring the return of the object from illegal possession based on civil vindication.

It should be noted that national courts refuse to recognize foreign bans on the export of cultural objects as one of the grounds for not recognizing property rights. Since these prohibitions are of a public legal nature. Private law doctrines that allow interpretation in the context of public law, recognized as having public legal nature and on this basis, shall not apply to the dispute. Thus, English courts did not recognize the New Zealand legal norms on the prohibition of the export of cultural objects as a basis for non-recognition of property rights. ${ }^{30}$

29 Siehr K. , Vereinheitlichung des Mobiliarsachenrechtes in Europa, insbesondere im Hinblick auf Kulturgüter, RabelsZ (1995) S. 454, 462.

30 Attorney-General of New Zealand v Ortiz, Case Reference [1984] AC 1; [1984] 2 WLR 809; [1983] 2 All ER 93; [1983] 2 Lloyd's Rep 265. 
The English court also decided in the Iran v. Barakat, recognizing that Iranian rules on the export of cultural goods are part of the criminal law and therefore not applicable in the United Kingdom. ${ }^{31}$

The Italian case of De Contessini is typical. ${ }^{32}$ The problem was that a stolen cultural object from France was acquired in good faith by an Italian collector. The Italian court did not recognize the illegality of the export of the object, which, moreover, according to French Law, was recognized as a historical monument, excluded from civil circulation and not subject to acquisitive prescription, used to determine the bad faith in the acquisition of property rights. The stolen cultural object was recognized under Italian Law as acquired in good faith by an Italian collector. It should be noted that the UNESCO Convention on the Means of Prohibiting and Preventing the Illicit Import, Export and Transfer of Ownership of Cultural Property was not in force at that time in relations between Italy and France.

In the case of Indian coins that were illegally exported from the territory of India, the Court, by deciding a civil case in Switzerland on a claim for vindication, refused to apply Indian Administrative Law on the rules for the export of cultural objects. The court found under Article 19 of the Law on Private Intenational Law that the applicable law is Swiss law. This mattered because the coins were under security in Switzerland. As a result, the pledge was found to be legal under Swiss Law. The court indicated that Switzerland, at the time of the bail, did not have international obligations to return the illegally exported cultural objects. Thus, the return of the coins to India was not carried out. ${ }^{33}$

Under the conditions of the UNIDROIT Convention, international treaties, and the European Union Law, such court decisions have become currently impossible. However, in the absence of international and European legal norms, the courts proceed from the concepts of purely national law.

\section{Impact of European Union Law}

\subsection{The freedom of movement of goods and objects of culture}

Freedom of movement of goods and cultural objects are closely interconnected. The freedom of movement of goods belongs to one of the four fundamental freedoms of the internal market in European Union Law. Under Articles 34 and 35 Treaty on the functioning of the European Union (hereinafter - the Treaty) trade barriers between the countries of the European Union are not allowed.

Article 34 of the Treaty provides that quantitative restrictions on imports, as well as any equivalent measures, are prohibited between member states. Article 35 of the Treaty contains a

31 Government of the Islamic Republic of Iran v The Barakat Gallery Ltd, Case No: A2 / 2007/0902 / QBENF, Royal Courts of Justice Strand, London, WC2A 2LL 21/12/2007.

32 French Ministry of Culture v. Italian Ministry of Culture and De Contessini, Cass. 24 November 1995, n. 12166.

33 Beat Schönenberger, Restitution von Kulturgut, Anspruchsgrundlagen - Restitutionshindernisse - Entwicklung, Stämpfli Verlag AG Bern - 2009, p. 166. 
similar provision, which prohibits between Member States quantitative restrictions on exports and any measures having equivalent effect.

The operation of the norms of Articles 34 and 35 of the Treaty for the circulation of cultural objects implies the abolition of all restrictions on the import and export of objects between the European Union Member States. This approach meant the abolition of control in this area, which would equate cultural objects with ordinary goods and, accordingly, meant the abolition of state control over their sale and restrictions on export abroad. ${ }^{34}$

It should be noted, however, that Article 36 of the Treaty permits prohibitions or restrictions on imports, exports, or transit that would be justified on the grounds of protecting a national heritage of artistic, historical, or archaeological value. Such prohibitions or restrictions must not become a means of arbitrary discrimination or a disguised restriction on trade between Member States. Analysing the peculiarities of the application of Article 36 of the Treaty as a basis for prohibiting or restricting the circulation of cultural objects in the EU, the category of cultural object itself is differentiated.

On this basis, the European Court of Justice, interpreting EU law, recognized as a result cultural objects as a commodity under the Article of the Treaty, as well as the right of EU member states to apply restrictive measures under EU law. ${ }^{35}$ This practice has contributed to the development of the so-called clause of exceptions and limitations under Article 36 of the European Union Treaty. The definition of cultural objects as having artistic, historical, or archaeological value and in respect of which restrictions can be applied that do not violate the freedom of movement of goods remains an urgent issue. Since in national law, the legal meaning of cultural objects is different.

The law of the European Union member states contains rather vague legal categories, similar to Article 36 of the Treaty. They are specified by national legislation, which must comply with the European Union legal requirements.

The European Court of Justice has not unequivocally interpreted the definitions of cultural objects in European Union law, thereby leaving this issue open. This is an understandable point of view of the court since the court is called upon to resolve conflicts, and not to establish a normatively similar framework.

The starting point for the Court is the recognition of the properties of goods in the European Union internal market for cultural objects.

The existing case law allows us to draw the following conclusions. On the one hand, the application of Article 36 of the Treaty is an exception, not a rule in the field of freedom of movement of goods. The grounds for restrictive measures should be interpreted narrowly and not broadly.

On the other hand, European Union Member States are granted the right to apply restrictive measures to protect cultural sites of artistic, historical, or archaeological value.

34 Anette Hipp, Schutz von Kulturgütern in Deutschland Walter de Gruyter Verlag, Berlin - New York 2000, S. 159.

35 Judgment of the Court of 10 December 1968. Commission of the European Communities v Italian Republic. Case 7-68. 
States have the right to regulate this area, however, within the limits of not abusing their rights. For example, European Union member states cannot completely prohibit the export of antiques and cultural values, as well as objects that do not have special cultural and historical significance. Such an absolute prohibition would be contrary to Article 36 of the Treaty. ${ }^{36}$ Therefore, the national regulation of the export of cultural objects is of practical importance for the application of Article 36 of the Treaty.

It should also be noted that the European Court of Justice uses in its practice other grounds to justify the restrictions applied. This is how the Court assessed the norms on the legal protection of books based on the protection of public interests. ${ }^{37}$ The existing prohibitions and restrictions on the sale or export of cultural objects must comply with the requirements of European Union Law. This concerns the requirements to obtain permission to export a cultural object and fill out customs declarations. As a rule, such requirements do not correspond to the law of the European Union internal market, however, as an exception, they are recognized as legitimate based on Article 36 contracts, as well as adopted secondary European Union Law.

\subsection{Specific features of Directive 2014/60/EU}

\subsubsection{Scope}

In European Union Law, the return of cultural objects is regulated by Directive 2014/60/ EU, which is a codified version of Directive 93/7/ EEC, amended by Directive 96/100/EC, and Directive 2001/38/EC. The current Directive 2014/60/EU covers the legal control requirements for the export of cultural objects.

Directive 2014/60/EU regulates the return of illegally exported cultural objects. An object that was illegally exported from the territory of the state in which it was located is subject to return. A cultural object, under Article 2 part 1 of the Directive, will be "illegally displaced from the territory of a member state" if it has been moved from the territory of a member state in violation of their rules for the protection of national values or violation of Regulation (EC) No 116/2009, as well as not returned to the end the period of legal temporary relocation or any violation of other conditions governing such temporary relocation This regulation will not apply to the export of a cultural object outside the EU, i.e. to a third country.

It should also be noted that the issues of transfer of ownership are not significant for the norms of the Directive 2014/60/EU. Moreover, under Article 13 of the Directive, the ownership of the cultural object after its return is determined based on the law of the requesting Member State. This means that ownership is not determined by the law of the state where the object is located at the time of the request.

About the object of culture is subject to return despite the form of ownership and legal status of the owner, Article 3 of the Directive explicitly provides that cultural objects that have been illegally exported from the territory of a member state are to be returned by the procedure and under the conditions provided for in the Directive, which introduces certain legal terminology that differs from the terminology of traditional civil law. Particular importance is

36 Grabitz Hilf Nettesheim, Das Recht der Europäischen Union, Art. 36 AEUV, 2015, Rdnr. 31.

37 Judgment of the Court (Second Chamber) of 30 April 2009, Fachverband der Buch- und Medienwirtschaft v LIBRO Handelsgesellschaft mbH, Case C-531/07. 
given to the term "return", which means the physical return of cultural property to the territory of the requesting Member State. And also the term "owner", which means a person who physically holds a cultural object for himself. Then the term "holder" refers to the person who physically holds the cultural property for a third party. It should be noted that the Directive provides for the state rights for the filing of a claim. The Directive does not provide for the participation of other persons as a plaintiff, which should be perceived critically, since not only the state is the owner of cultural objects, but also other subjects.

A specific feature of the Directive's application is the time limit. Directive 2014/60/ EU applies only to cultural properties that have been illegally removed from the territory of the Member States after January $1^{\text {st }}, 1993$ (Article 14 of the Directive). As known, on January ${ }^{\text {st }}$, 1993, the legal regime of the European Union internal market came into force.

The norms of the Directive can be applied retrospectively - before the entry into force of the European Union internal market, that is, until January $1^{\text {st }}$, 1993. This requires a special implementation of legal regulations. The Directive gives the public institutions of each state the right to choose the retrospective application of the provisions of Directive 2014/60/EU.

The time constraint presents an obstacle to the application of the special mode of the directive. In other cases, the rules of civil law will apply.

\subsubsection{Time limits for filing a claim for the return of a cultural object}

The Directive 2014/60/EC resembles the system of relative and absolute timing of the UNIDROIT Convention. Under Article 8 part 1 of the Directive, Member States shall provide in their legislation that the return proceedings cannot be initiated later than 3 years after the requesting Member State detects the location of the cultural object and identifies the owner (owner or holder). The period of one year is a relative term. Absolute terms for claiming are subsequently introduced.

Article 8 of the Directive provides that such a procedure, in all circumstances, cannot be initiated later than 30 years after the illegal movement of the object from the territory of the requesting Member State. However, if the object is part of a public collection or church inventory, and they are specifically protected by the provisions of national law, the return procedure can be carried out within a 75-year period or, based on a bilateral agreement, the limitation period is over 75 years. The terms of 30 years and 75 years are characterized as absolute terms.

The Directive also provides for the possibility of not applying any statute of limitations. It should be noted that the Lithuanian lawmaker did not provide for the non-application of deadlines in the law on the protection of movable cultural objects.

Return requirement will not be considered if the requesting State has subsequently agreed to the export of cultural objects and does not regard its illegal export.

In addition, the return procedure will not be implemented, if it subsequently turns out that the removal from the territory of the requesting Member State is no longer illegal. The situation is possible if the legal acts that make the export of a cultural object are changed that do not contradict legal requirements.

The main reason for refusing a refund in practice is missing the deadline for filing a claim. The reason for this is bureaucratic obstacles, a belated reaction of the competent authorities 
to information about the location of a cultural object, untimely execution of documents for a return request, and preparation of a statement of claim to the court of the state where the cultural object is located.

\subsubsection{Compensation}

Following Article 10 of the Directive, when deciding on the return of cultural property, the court awards compensation to the owner that is fair in the circumstances of the case, ensuring that it covers the owner's costs of care and attention paid to the property. The requesting Member State pays compensation upon return of the object.

The claim for payment of compensation is made based on the law of the requested state, i.e. the state in which the illegally exported object is located.

The Directive specifically deals with the transfer of rights in the event of inheritance, which will not be the basis for terminating the procedure for returning the object, and the person who inherits the object will not enjoy a more favorable position than the person from whom he received this object on this basis.

The payment of fair compensation and costs is without prejudice to the right of the requesting Member State to claim compensation against the person responsible for the illegal removal of the cultural property from its territory.

The right to claim belongs on the basis of the norms of the directive to the State. This means that a State acts as a plaintiff in the case, then at the end of the process, the returned cultural object is transferred to its owner based on the legal norms of the plaintiff's state. In practice, a rather complicated and contradictory situation is developing. Therefore, such processes are rare.

Other subjects may base their claims on the norms of civil substantive and procedural law. Depending on the peculiarities of the national system of law, the norms of the Directive that are implemented in the national system may apply not only to states. This feature was implemented in Lithuanian Law, recognizing not only the state but also other entities the right to claim.

The specific provisions of Directive 2014/60/EU concerning the return of cultural objects have been implemented in Article 16 of the Law on the Protection of Movable Cultural Objects. ${ }^{38}$

\section{Restoration of the rights of former owners of cultural objects in the judicial practice of Lithuania}

A real test for the Lithuanian legal system was the restoration of the rights of the former owners of cultural objects. The problem was the lack of legislation, which provided for the conditions and procedure of restoration of the rights of former owners of cultural objects. The Lithuanian lawmaker focused on restoring the rights of former owners to the preserved real

38 Bulletin of the Republic of Lithuania , 2014 Nr. XII -1293. 
estate, leaving without due attention the issues of ownership of the surviving movable property (including cultural objects).

Cases that arose about the return of surviving cultural objects that had been illegally nationalized during the Soviet era became not only the subject of civil, but also of constitutional litigation.

The return of cultural objects was analysed in the decision of the Constitutional Court of the Republic of Lithuania on March $16^{\text {th }}, 1999,{ }^{39}$ that decided the constitutionality of the legal provisions of the Law on Museums of the Republic of Lithuania, by which cultural objects in museum funds were not subject to return. It was from this case that the problem of returning cultural objects became obvious to the legal system of the Republic of Lithuania. Since the issues raised by the Court were central to the perception of ownership and the restoration of the rights of former owners to it. In the process, the problem of the relationship between public and personal interests was solved.

Lithuanian constitutional jurisdiction has certain peculiarities. In particular, a private person who believes that his or her constitutional rights have been violated cannot directly initiate constitutional review. This situation persisted until 2019. The function of protecting constitutional rights is performed by the Courts, which, when considering a claim of a private person, are obliged to apply to the Constitutional Court with a request for the constitutionality of the applicable law or other legal act. Such a duty is justified by the possible non-constitutionality of law or other legal act. If the court concludes that such a situation is possible, then it is obliged to suspend the case under consideration and send a request to the Constitutional Court. Courts interpret the duty of requesting the constitutionality of a legal act in different ways.

The Vilnius City District Court, considering the case in the first instance, rejected the plaintiff's claim. The Vilnius City County Court, having considered the plaintiff's appeal, kept the decision of the Vilnius Court unchanged. Only by examining the civil case on the cassation appeal of the plaintiff against the ruling of the court of appeal, the Supreme Court of Lithuania concluded that the process should be suspended and the Constitutional Court should be asked for compliance with Article 23 of the Constitution, Article 5 part 2 of the Law on Museums of the Republic of Lithuania. As can be seen from the circumstances of the case, only the Supreme Court decided to initiate the constitutionality procedure, since the legislative prohibition on the return of cultural objects to the owners from whom they were illegally confiscated by the Soviet state may contradict Article 23 of the Constitution of the Republic of Lithuania on the protection of property rights.

The Constitutional Court of the Republic of Lithuania accepted the request of the Supreme Court of Lithuania for proceedings, which was reasoned as follows. The plaintiffs father was sentenced on September 15 ${ }^{\text {th }}, 1951$ to 10 years of forced labour camps by a special meeting at the USSR Ministry of State Security for aiding and abetting the German occupiers and Anti-Soviet agitation, his property was confiscated. ${ }^{40}$ Among other things, 27 paintings

39 Resolution of the Constitutional Court of the Republic of Lithuania On Compliance with the Constitution of the Republic of Lithuania dated March 16, 1999 On Compliance with the Constitution of the Republic of Lithuania Art. 5 of the Law on Museums.

40 Extract from the minutes $\mathrm{Nr}$. 41 Special Meeting of the Ministry of State Security of the USSR on September 15, 1951. The data of the Lithuanian Special Archive of the F. SB Ap . P 12197, 1. 24. 
from his private collection were confiscated, which, based on a confiscation act dated October $12^{\text {th }}, 1951$, ended up in the funds of the Vilnius State Museum of Art.

On May $23^{\text {rd }}, 1989$, the plaintiff's father was rehabilitated posthumously based on Article 1 of the Decree of the Presidium of the Supreme Soviet of the USSR on January $16^{\text {th }}$, 1989. Additional measures to restore justice concerning the victims of the repressions that took place in the period 30-40s and early 50s. His civil rights were restored. After the declaration of independence of the Republic of Lithuania on March 11 ${ }^{\text {th }}, 1990$, the rights of the repressed were also subject to restoration.

The plaintiff, who is the heir to his father, applied to the court with a demand to return the illegally confiscated paintings from the funds of the current Lithuanian Art Museum. The claim was dismissed based on Article 5 part 2 of the Law on Museums of the Republic of Lithuania, which stated that museum values that make up the state museum fund are state property and cannot be returned to their former owners.

According to the applicant, the legislative regulation may not meet the requirements of Article 23 of the Constitution, which establishes that property is inviolable, and the right of ownership protected by Law. The seizure of property is possible only by the procedure established by Law for public needs and with fair compensation.

Interpreting Article 23 of the Constitution on guarantees of property, the Constitutional Court concluded that a cultural object is not only an object of property rights but also a public value. Thus, the specificity of legal regulation is substantiated, which combines private and public interests. Besides, the Constitutional Court interpreted the rights of citizens to restore violated rights as a result of the confiscation of property during the Soviet era, recognizing that while there is no special legal regulation at the legislative level on the restoration of rights, persons whose rights have been violated have any subjective rights to restoration. According to the Constitutional Court, special legislative regulation is needed to implement these rights, which is the prerogative of the legislative branch, then it makes sense to talk about subjective rights in this area.

In the Lithuanian legal system, a law was passed on the restoration of rights to immovable property, which did not provide for the restoration of rights to movable property. Thus, in the legal system, in the opinion of the Constitutional Court, there is a legal gap that the legislator must fill. At this stage of constitutional jurisdiction, the court refrained from addressing the situation, not pointing to a gap in the law, but recognizing the right of former owners to compensation in cases of unlawful seizure of property from ownership. One can only regret that in 1999 the Constitutional Court did not dare to fill the gap in the law itself.

The Constitutional Court concluded that Article 5 part 2 of the Law on Museums does not contradict the Constitution in terms of prohibiting the return of cultural property held in museum funds before the restoration of the independence of the State of Lithuania. Even if these values are illegally owned by the state.

This case has exposed an additional problem of the relationship between the constitutional review and the jurisdiction of ordinary courts. The absence of a special law cannot limit the protection of the civil rights of individuals. It makes no sense to wait for the adoption of the law when the case is subject to consideration. The function of the court is to fill a gap in the law, 
rather than wait for the legislative act of parliament to be passed, which will serve as the basis for a judicial decision. In addition, the rights of the owner can be protected not only by the return of paintings from the museum fund but by other means, such as payment of compensation to the former owner or his heir.

As a result of a lengthy process, the State of Lithuania paid monetary compensation to the plaintiff for the seized paintings. The court of the first instance awarded compensation to the plaintiff, guided by the principle of protection of property rights based on Article 23 of the Constitution of the Republic of Lithuania. ${ }^{41}$ The trial lasted in the Lithuanian courts until 2014.

It took the Lithuanian legal system 15 years to go through this category of court cases to an obvious solution. The Lithuanian legislator has not yet adopted a law on the restoration of the rights of former owners to movable property.

\section{Return of German Cultural Objects in Lithuanian Judicial Practice}

The issue of restoring the rights of owners is closely related to the litigation on the return of German cultural objects that ended up on the territory of Lithuania after World War II. In the legal literature, this situation is called the situation with the personal trophies of military personnel. ${ }^{42}$ Subsequently, the captured property troops officially or secretly received for sale or in any other way to legalize. It should be noted that some of the cultural objects were simply missing.

The Ministry of Foreign Affairs of the Federal Republic of Germany applied in practice the conclusion of intergovernmental agreements on cooperation in the field of culture, which included provisions on the return of such cultural objects. Article 16 of this agreement concluded with the Republic of Lithuania states that the parties agree that the missing or illegally exported cultural property located on their territory should be returned to the owners or their heirs.

The implementation of this article has become a key issue in the litigation between the Federal Republic of Germany, the Prussian Cultural Heritage Foundation, the Republic of Lithuania, the State Museum of Art of Lithuania, and a private person A.V.K. ${ }^{43}$

All participants in the process claimed ownership of two paintings that ended up on the territory of the Republic of Lithuania after World War II. The fact is that the fate of works of art was quite common for that time, but their legal assessment was rather ambiguous.

The paintings survived the Military, Civil and Criminal Law of the USSR, as well as the Lithuanian Soviet Socialist Republic - LSSR. After the Declaration of Independence of the Republic of Lithuania, the legal status of paintings based on Lithuanian Law will apply to European Union Law and UNIDROIT Convention.

In the field of protection of cultural property, the object itself occupies a special place. The trial was about the return of the painting by Adolph Menzel "After the Ball", as well as the painting by Antonio Campi “The Three Maries at the Grave of Christ". Determining the

41 The decision of the Vilnius District Court on October 25, 2010 The civil case Nr . 2-39-560 / 2010.

42 Boguslavsky M.M. Cultural values in international circulation - legal aspects, Moscow - Norma, 2015, p. 286, Carl, Güttler, Siehr, Kunstdiebstahl vor Gericht, City of Gotha v. Sotheby's / Cobert Finance SA, 2001, De Gruyter, S. 52.

43 The article uses the initials of an individual. 
ownership of paintings is the main issue for their return. Since in the process the question is being decided to whom to return and based on which legal acts to determine the possible loss or acquisition of property rights, the circumstances of the acquisition of the paintings were as follows. Adolph Menzel's painting "After the Ball" was bought for 3,000 Reich marks by the Prussian Ministry of Culture in 1885 and transferred to the Berlin National Gallery. The painting is a multi-colored graphic that was rare in Adolph Menzel's work. ${ }^{44}$

The painting by Antonio Campi "The Three Maries at the Grave of Christ" was acquired in 1881 by the Royal Court of Frederick III. The work of art dates back to 1561. The Italian artist depicted the resurrection of Christ. ${ }^{45}$

By the end of World War II, these paintings were on the territory of Germany in special storage facilities to ensure their safety from hostilities, in particular bombings.

After the surrender of Nazi Germany, these territories came under the control of the Soviet military zone.

Leaving the occupied territories in the places where the paintings were stored, the Soviet Army units found massive losses of cultural objects that remained there. Among these missing were paintings by Adolph Menzel and Antonio Campi. The size of the paintings was not difficult to transport in ordinary hand luggage. For a long time, it was believed that the paintings were missing or were destroyed during the hostilities. However, these paintings ended up on the territory of the then Lithuanian Soviet Socialist Republic. Both paintings were in private collections, and then ended up in the State Museum of Art, but in different ways.

Adolph Menzel' painting "After the Ball” was bought in 1948 by the Council for Arts under the Council of Ministers of the Lithuanian Soviet Socialist Republic from a private person, who sold the painting for 4450 soviet rubles. The purchase and sale agreement has been preserved in the archives of the museum.

Antonio Campi's painting "The Three Maries at the Grave of Christ" was transferred after confiscation from a private person who was convicted of anti-Soviet activities. The confiscation was carried out by the authorities of the Ministry of State Security. The 1951 Confiscation Act is also in the archives of the museum.

In court, the rights to return the paintings were presented by the plaintiffs - the Federal Republic of Germany and the Prussian Cultural Heritage Foundation. The defendant, the Republic of Lithuania, together with a third party, the State Museum of Art of Lithuania, asked to dismiss the claim of the plaintiffs, considering the State of Lithuania to be the owner of the paintings. In addition, the third person, private person A.V.K, supported the position of the defendant, considering the painting illegally confiscated from her family as the owner and demanding compensation in the amount of its market value.

The Prussian Cultural Heritage Foundation, which, based on the Law on the Establishment of the Prussian Cultural Heritage Foundation and the transfer of the property values of the former land of Prussia to the Foundation of 2507 1957, presented its rights as

44 Bescheinigung Über die Eigentumsverhältnisse an dem Gemälde Aschermittwochsmorgen von Adolph von Menzel zur Vorlage beim Bezirksgericht Vilnius, 13 September 2012.

45 Bescheinigung Über die Eigentumsverhältnisse an dem Gemälde Drei Marien am Grabe von Christi von Antonio Campi zur Vorlage beim Bezirksgericht Vilnius, 10 September 2012. 
an owner to the painting by Adolph Menzel "After the Ball". ${ }^{46}$ The Foundation, as the legal successor to Prussia, disposes of the items specified in Article 2 of the specified law property, which includes cultural objects. Based on Article 3 part 2 of the same Law, the Foundation has the right to bring claims, as well as take other actions to return cultural property lost as a result of the war.

The rights of the owner to the painting by Antonio Campi "Three Maries at the Grave of Christ" were presented by the Federal Republic of Germany, which acted as a plaintiff in the case, and a private person A.V.K. who participated in the process as a third party.

The Federal Republic of Germany acted as the legal successor since the painting was stolen from the territory that later belonged to the German Democratic Republic (hereinafter the GDR). After the accession of the GDR to the Federal Republic of Germany in 1990, the property to which the GDR could lay claim was transferred as a legal successor as federal property to the Federal Republic of Germany. The legal basis is Article 21 (Property of the Administration) and Article 22 (Financial Property) merger agreement.

The legal successor in the case was the private person A.V.K., who is the direct heir to the owner of the painting from whom it was confiscated by the organs of the USSR Ministry of State Security.

According to A.V.K., her father was the bona fide owner of this painting. In the very process, A.V.K .claimed its rights as the heir to the owner of the painting with a demand to reject the claim of the Federal Republic of Germany. The fact is that A.V.K. filed a claim for compensation for the painting, which was in the proceedings of the County Court of the City of Vilnius. The case pending by the court was suspended pending a decision by the Court to return the painting to the Federal Republic of Germany.

Therefore, the case for the return of the painting was important not only for the plaintiff of the Federal Republic of Germany, demanding the return of the painting, but also for resolving the issue of compensation, and who will pay it depending on the outcome of the case.

It was not ruled out in the proceedings that compensation could have been awarded from the plaintiff of the Federal Republic of Germany or the defendant of the Republic of Lithuania. Since the reclamation of the painting in case of recognition by the owner of a bona fide acquisition is subject to compensation, which is paid to the owner of the painting. In addition, the defendant himself had every right to raise the issue of compensation for paintings that were under the jurisdiction of the State Museum of Art of Lithuania.

In the practice of courts of other states, claims for the return of cultural objects are faced more with the problem of terms for filing claims than with determining the owner. ${ }^{47}$ The Lithuanian case was no exception, where the problem of qualifying the terms and the moment of their counting turned out to be the central problem.

In the case of the painting by Antonio Campi "The Three Marys at the Grave of Christ", the court of first instance concluded that the plaintiff in the Federal Republic of Germany

46 BGBI. IS. 2785

47 K. Siehr, Prozesse über geschütztes Kulturgut in Deutschland, KUR, 2012/1, S. 5. 
missed the prescription term for filing a statement of claim from the moment when the plaintiff learned about the location of the painting and its ownership. ${ }^{48}$

In the case of the Federal Republic of Germany's claim, the term was determined by 3 years, since at that time the current law provided for a similar duration of the term.

The legislative provision on the timing has its origins in Article 3 of the UNIDROIT Convention. The Lithuanian lawmaker has implemented the legal norms of the UNIDROIT Convention in Article 24 of the Law on Protection Movable Cultural Property of the Republic of Lithuania.

As a result, a rather peculiar situation has arisen, since the legal provisions of international treaties apply to states that are not parties to this international treaty.

On the one hand, although Germany participated in the development of the UNIDROIT Convention, it did not subsequently ratify it, pointing out the incompatibility of the legal concept of the convention with the basic principles of German Civil Law. First of all, this refers to the principle of a bona fide owner in the civil property law of the Federal Republic of Germany. The legal provisions of the Convention do not apply to the Federal Republic of Germany. Accordingly, in the legal system of the Federal Republic of Germany, there are no adopted UNIDROIT conventions either. In the legal doctrine, there is still a discussion about the advisability of participating in the Convention. The prevailing opinion is against the Federal Republic of Germany's participation in the legal regime of the Convention. It should be noted that the German doctrine expresses regret over the Federal Republic of Germany's failure to ratify the UNIDROIT Convention. ${ }^{49}$

On the other hand, by participating in the internal process of the state, the plaintiff acts based on the requirements of Lithuanian Law. Article 24 of the Law on Protection Movable Cultural Property provided for certain requirements that were applied at the time of filing a claim to all cases related to the return of cultural objects.

In this regard, a rather specific situation arose when legal norms were applied to a state not a party to the Convention as a party to the Convention. It should be noted that such a situation is impossible in the Federal Republic of Germany.

Considering the specifics of its case, Germany in the lawsuit argued its position concerning the timing in a different way. According to the plaintiff, the court should have applied the general statute of limitation, and not the special ones. The general limitation period is 10 years, which begins in this case from the moment of establishing the location of the painting by the plaintiff.

For the Federal Republic of Germany, such an interpretation of legal norms was consistent with the principles of competition of legal norms, since the use of special terms does not presuppose the application of general terms. The application of the statute of limitation under the Civil Code was consistent with the implementation of Article 16 of the intergovernmental agreement on cultural cooperation between the Republic of Lithuania and the Federal Republic of Germany that served as the legal basis for a claim of return.

48 The decision of the Vilnius District Court on February 15, 2015, civil case Nr . 2-172-450 / 2013.

49 Bettina Thorn, Internationaler Kulturgüterschutz nach der Unidroit-Konvention, De Gruyter Recht Berlin, S. 194. 
It should be noted that in the intergovernmental agreement there were no deadlines for filing claims for the return of cultural objects. Therefore, it has been suggested that statutes of limitation do not apply at all to such claims. Such a norm is applied in the Federal Republic of Germany Law, as well as in the Lithuanian Law concerning national cultural objects that have been removed from their territories.

Also, according to the author, it would be wrong from the point of view of the right to apply the legal norms of the UNIDROIT Convention for subjects of states that are not parties to this. The application of the special provisions of the Convention concerning the Federal Republic of Germany was a non-standard decision.

The peculiarity of the situation was also in the fact that later the legislator changed this part of the law on the time limits for filing a claim, setting the time limit under the provisions of Directive 2014/60/EU (former Directive 93/7/ EEC). The norms of the directive have a peculiarity in effect in time. The directive has been applied to cases of illegal export since 1993. By adopting the directive, the state can extend the directive to cases up to 1993. The Republic of Lithuania acted under Article 15 of Directive 2014/60/EU. The action was not extended to cases until 1993.

A time-limiting regulation is included in the Decree of the Government of the Republic of Lithuania of August 31 $1^{\text {st }}$, 2004 On Approval of the Rules for Return of Illegally Exported Cultural Objects from the Territory of a Member State of the European Union ${ }^{50}$

This means that the legal provisions of the directive, implemented in the regulation and the law, must apply to cases of illegal export of cultural objects from European Union member states after January $1^{\text {st }}, 1993$.

The legal regulation of the terms associated with the requirement to return cultural objects is not unambiguous. Much depends on how correctly the legal relationship is qualified. Lithuanian Courts' decisions were based on the specifics of the requirements for the return of cultural objects. Therefore courts applied the rules in force at the time of filing the claim. The Court considered it possible to apply a special rule on the timing of the implementation of Article 16 of the intergovernmental agreement, which has not entered into force but is temporarily applied in relations between Lithuania and the Federal Republic of Germany.

From the point of view of practice, the rules on timing are a stumbling block in court cases on the return of cultural objects. It was the failure to meet the deadlines that led to the dismissal of the claims. This is what the Vilnius County Court did, stating that it rejected the claim of the Germany on the grounds that the three-year period for filing a claim had been missed.

The court ruled that the plaintiff had missed the indicated deadline because he knew the location of the painting in the Lithuanian Art Museum. The reason was the request of the director of one of the many German museums about the paintings lost during World War II. The correspondence has been preserved in part and only in a copy. The court was provided with a translation of the letter into Lithuanian.

Also, a third party provided publications in the Lithuanian press condemning the fate of cultural values lost after World War II. The fact is that in newspaper articles, interviews were

50 Bulletin of the Republic of Lithuania, $2004 \mathrm{Nr}$. 135-4900. 
allegedly given by officials of the Federal Republic of Germany, who could initiate the process of returning the painting. The Vilnius County Court, considering the case in the first instance, considered the provided evidence sufficient to conclude that the plaintiff was late in submitting the demand for the return of the paintings.

In the case of the return of Adolph Menzel's painting, the Prussian Cultural Heritage Foundation, being also a plaintiff, did not miss the specified time limit. The court found that there was not enough reliable evidence that the plaintiff knew about the location of Menzel's painting in the Lithuanian Art Museum for more than three years. The claim of the Prussian Cultural Heritage Foundation was satisfied by the Lithuanian court, and the painting was subject to return.

It should be noted that the issue of timing was not the only one. For such processes, it is important to establish the circumstances of the disappearance of the paintings, as well as their illegal export from Germany.

The plaintiffs indicated that the paintings disappeared from their storage sites. The fact of the loss was established after the surrender of the warehouse guard by the Soviet Army.

The defendant believed that such data was not enough to establish the ownership of the paintings. In his opinion, the paintings could be sold or donated, as well as otherwise could get into commercial circulation. The defendant tried to emphasize the good faith of the acquisition of these paintings by the Lithuanian side, as well as the fact that the plaintiffs did not prove that the paintings belonged to them and disappeared under the circumstances indicated by them.

A third party A.V.K. claimed ownership of A. Campi's painting. Oddly enough, it was A.V.K. that presented part of the correspondence between the Lithuanian and German museums, as well as excerpts from newspaper publications in which the fate of German cultural values displaced to other countries was discussed. The interview also mentioned A. Campi's painting, which belongs to the Federal Republic of Germany. Recognition of the owner's rights to A. Campi's painting for A.V.K. would mean recognition of its right to compensation. Under certain circumstances, A.V.K. could claim compensation from the Federal Republic of Germany.

The result of the case in the court of the first instance was the rejection of the Federal Republic of Germany's claim against Campi's painting "The Three Maries at the Tomb of Christ" since the plaintiff missed the three-year deadline for submitting his claims for the return of the painting and satisfaction of the claim of the Prussian Cultural Heritage Foundation about Menzel's painting "After the Ball”. In this case, the court did not establish a missing three-year term.

The trial went to the second instance. The appeals were submitted by the plaintiff of the Federal Republic of Germany, the defendant of the Republic of Lithuania, the defendant's side in their responses was supported by third parties A.V.K. and the Lithuanian Art Museum.

Germany challenged the decision of the Vilnius County Court in its essence The main arguments were as follows. The first instance court erroneously qualified the post-World War II relationship. The court had to apply Article 16 of intergovernmental agreement between Lithuania and Germany and qualify the terms based on the Civil Code of the Republic of Lithuania, i.e. the limitation period from the moment of establishing the location of the painting, which is 10 years. The Court could not base its reasoning on the law on the protection 
of movable cultural objects, since the law implements the provisions of the directive, which apply to cases of illegal export after January $1^{\text {st }}, 1993$. The disappearance of A. Campi's painting occurred in 1945; it was confiscated in the Lithuanian Soviet Socialist Republic in 1951.

It was obvious to the plaintiff that wartime did not fall under the regulation of Directive 2014/60/EU. The Federal Republic of Germany also stated that at that time it was not a member of the European Union, since the European Union had not yet been created. In addition, it should be noted that the 3-year term is based on the UNIDROIT Convention, which has not been ratified by the Federal Republic of Germany. Therefore, the provisions of the Convention should not apply to a state that does not participate in its legal regime.

In conclusion, the Federal Republic of Germany did not consider that it had violated the terms for submitting the statement of claim to the court. Since acted based on national law and the competent institutions, having received information about the location of the painting, they immediately presented a demand for its return.

The defendant fully agreed with the conclusions reached by the Vilnius County Court, therefore he asked the Lithuanian Court of Appeal to leave the decision of the first instance court unchanged. Third parties were completely on the defendant's side.

The plaintiff The Cultural Heritage of Prussia Foundation did not file an appeal, since the foundation's claim for the return of Menzel's painting was fully satisfied by the Court, which could not be said about the defendant, the State of Lithuania. The defendant's appeal was related to a part of the court's decision on the return of A. Menzel's painting. According to the defendant, A. Menzel's painting was bought officially and is legally kept in the Foundations of the Lithuanian Art Museum. The Republic of Lithuania is a bona fide purchaser. The plaintiff did not prove the circumstances that the painting was stolen and then illegally exported from the territory of Germany. The defendant asked to dismiss the plaintiff's statement of claim on these grounds. Their demands were supported by all the third parties involved.

As a result, the Lithuanian Court of Appeal, having considered the appeals of the parties, upheld the decision of the Vilnius Regional Court unchanged. ${ }^{51}$

The decision of the Lithuanian Court of Appeal was based on the motives of the Vilnius County Court. The Court of Appeal recognized that the claimant from the Federal Republic of Germany, although he has the right to demand the return of the painting, still did not comply with the procedural requirements and missed the 3-year deadline for filing a claim. Critically, it should be noted that the Court of Appeal did not take into account who and how could potentially notify the plaintiff about the location of the painting, and from a subjective point of view, whether the plaintiff understood that he was notified. Following the practice of the Court, it turned out that the Federal Republic of Germany would be considered notified of the location of the painting even if a German tourist noticed A. Menzel's painting in the museum. The Court was not guided by the criterion that certain state institutions should be notified of the whereabouts of the painting and the action or inaction of which can be equated with the state. The court also did not analyse the possibility that the plaintiff should have known about the location of the painting in the Lithuanian Museum.

51 Judgment of the Lithuanian Court of Appeal dated November 8, 2013. Civil case Nr . 2A-1809/2013. 
Regarding the defendant's claims to cancel the decision of the Vilnius County Court regarding the return of A. Menzel's painting based on a bona fide acquisition of it in time to the Lithuanian Soviet Socialist Republic - LSSR, the Court of Appeal noted that the purchase and sale agreement of the painting did not impede the implementation of Article 16 in intergovernmental agreements on cultural cooperation between Germany and the Republic of Lithuania. The fact of the export from the territory of Germany was enough for the court to recognize the grounds for returning the painting to its current owner, the Prussian Cultural Heritage Foundation. The court did not recognize the rights of the owner of the Republic of Lithuania to this painting. It should be noted that the compensation claim was not presented by the Lithuanian side, and therefore was not considered.

The decision of the Lithuanian ourt Appeal became final concerning A. Menzelss painting. The respondent The Lithuanian state did not file a further cassation appeal.

The German plaintiff filed a cassation appeal against part of the court decisions on the non-return of A. Campi's painting.

The Supreme Court of Lithuania, by analysing the circumstances of the case, recognized that the lower courts incorrectly qualified the three-year term provided for in the law on the protection of movable cultural objects as a limitation period.

According to the Supreme Court, the plaintiff did not miss this deadline, since the Federal Republic of Germany institutions were not informed about the location of the painting on the date set by the lower courts. According to the court, the plaintiff was informed later and was not late in filing the statement of claim. This position of the court meant that Campi's painting "The Three Maries at the Grave of Christ" was subject to the return of the Federal Republic of Germany. ${ }^{52}$

The Court rejected the plaintiff's argument that the painting was missing. According to the court, this issue is a legal issue that was not discussed in the lower Courts, therefore the court was based on the illegal export of this painting from the territory of Germany.

It should be noted that the term of the missing painting was more acceptable in the opinion of the plaintiff. Moreover, illegal export is associated with violation of the rules for transporting cultural property abroad. The peculiarity of the case was that the paintings were taken out after World War II from the territory of Germany occupied by the USSR Army. The court should have indicated the legal act that was violated as a result of the export of A. Campi's painting. The court did not do this, so it was not clear what the illegal exportation was.

Boguslavsky, in his work "Cultural values in international circulation", analysed a similar situation, pointing to the secret directive of September $28^{\text {th }}, 1945$, Marshal of the USSR G.K. Zhukov, which regulated the procedure for the export of personal trophies of servicemen. There were no cultural objects in the list of things allowed for export. Therefore, Boguslavsky concludes that the export of cultural objects is illegal, in violation of the directive of the USSR Marshal..$^{53}$

52 Decision of the Supreme Court of Lithuania dated June 20, 2014. Civil case Nr. 3K-3-357 / 2014.

53 Boguslavsky M.M. Cultural values in international circulation - legal aspects, Moscow - Norma, 2015, p. 287. 
Interestingly, the decision of the Supreme Court does not indicate who exactly and how violated the procedure for export from post-war Germany, does not indicate the legal act that was violated. The Supreme Court based its reasoning on the decision of the Vilnius Regional Court, pointing out that, evaluating the evidence in the case, the Court is more inclined to believe that the painting was taken by soldiers of the Soviet Army from Germany. The court did not find convincing the arguments of the defendant and third parties that the painting could have been sold in Germany, or bought by a third party as a result of his commercial activities. The fact is that evidence was presented in the case about the activities of its former owner as a supply representative for the Independent Lithuanian Army. The position of the third party was understandable since it was trying to justify the bona fide acquisition of the painting. Guided by traditional ideas about the presumption in civil law, the plaintiff had to prove the bad faith of the acquisition of the cultural object, which after a long period seemed quite difficult.

However, applying Article 16 of the intergovernmental agreement between the Federal Republic of Germany and the Republic of Lithuania, the traditional presumption of civil law for the plaintiff to prove the owner's bad faith is transformed into the responsibility of the defendant to prove his discretion when acquiring a cultural object.

In this case, the return of the cultural object with the payment of compensation doctrine is applied. The right to compensation must be proven by the person claiming it. This means that evidence of the acquisition of the painting, the owner's discretion at the time, the acquisition costs, and the preservation of the painting during the period of its use must be provided. The defendant and the third party could not provide this data during the trial. Accordingly, the right to compensation could not be exercised.

A big surprise was the qualification of the applicable law by the Supreme Court. The plaintiff argued his position of Article 16 and the general limitation period for filing a claim in court, which is 10 years from the moment when the plaintiff learned about the discovery of the painting. However, the Supreme Court applied special provisions of the law on the protection of movable cultural objects by time limits, having established that the norms of the UNIDROIT Convention apply to entities from states that are not parties to the convention. In the opinion of the Court, the provisions of Directive 2014/60/EC also apply by analogy with law.

\section{Conclusion}

The Lithuanian legal system, when deciding the question of the relationship between International and National Law, proceeds from the positions of the Vienna Convention on the Law of Treaties, providing for the obligation to comply with international treaties. A peculiarity is that this provision applies to provisionally executable international treaties.

The European Union legal norms are recognized as an integral part of the legal system of the Republic of Lithuania. The Constitutional Court proceeds in its practice from a special clause on the Constitution of the Republic of Lithuania, which any other legal norms cannot contradict. 
The protection of cultural objects is under the jurisdiction of the member states of the European Union. Directly Article 36 of the Treaty on the Functioning of the European Union provides an opportunity, as an exception, to the member states of the European Union to restrict trade in cultural objects in respect of which the freedom of movement of goods is applied.

The legal provisions of the UNIDROIT Convention and Directive 2014/60/EU represent a compromise solution between the protection of the rights of the owner and the bona fide acquirer of a stolen or illegally exported cultural object.

In the Lithuanian legal system, several regimes have been created to protect the rights of the owner of a cultural object: the UNIDROIT Convention norms, the European Union Directive implemented norms, the norms of international treaties, as well as the National Law of the Republic of Lithuania. Differences in legal norms lie in the application of different approaches to protecting the rights of the owner of a cultural object. The protection of the property rights of a bona fide purchaser, based on the traditions of civil law, is opposed to the requirement, justified by International and European Union Laws, to return cultural objects with possible subsequent compensation to the owner. The evidentiary approach is different, which in the first case requires the owner to prove the bad faith of the acquisition by the owner, in the second case, on the contrary - the owner must prove the good faith of the acquisition to receive compensation from the owner.

The conflict of private and public interest became especially noticeable in the practice of the Constitutional Court of Lithuania, which recognized that cultural objects of museum funds are not returned to former owners. Lithuanian legal system took a long time, the state has recognized the right to payment of compensation and the former owner of the illegally confiscated objects of culture from the Soviet Age.

The problem of implementing the requirement for the return of cultural objects is a different application and legal qualification of the limitation periods provided for in the UNIDROIT Convention and Directive 2014/60/EU on the return of illegally exported cultural objects.

The practice of the courts of the Republic of Lithuania turned out to be ambiguous, as shown by the considered civil cases on the return of cultural objects to the Federal Republic of Germany and the Prussian Cultural Heritage Foundation.

Lithuanian Courts, implementing the norms of international and European Law, substantiate the return of cultural objects as an independent way of protecting the rights of the owner of cultural objects, which differs from vindication as the main way to protect the rights of the owner in civil law.

\section{Literature: Scientific literature}

Rene Lepeber, Treaties Provisional Application in: The Max Planck Encyclopedia of Public International Law, Volume X, Oxford University Press, 2012, p. 4.

Christa Roodt, Private International Law, Art and Cultural Heritage, Edward Elgar Publishing, 2015, p. 71. 
Sophie Vigneron, Protecting Cultural Objects: Enforcing the Illicit Export of Foreign Cultural Objects, in: Valentina Vadi, Hildegard EGS Schneider, Art, Cultural Heritage and the Market, Springer, 2013, p. 117.

Michael Anton: Handbuch Kulturgüterschutz: llegaler Kulturgüterverkehr , De Gruyter Verlag, 2010, S. 255.

Astrid Müller - Katzenburg, Internationale Standards im Kulturgüterverkehr und ihre Bedeutung für das Sach - und Kollisionsrecht, Dunker Humblot Berlin, S. 103.

V. Vadi and H. Schneider, Art, Cultural Heritage and the Market: Legal and Ethical Issues, in: Valentina Vadi, Hildegard EGS Schneider, Art, Cultural Heritage and the Market, Springer, 2013, p. 5.

Thorn, Bettina, Internationaler Kulturgüterschutz nach der Unidroit - Konvention, De Gruyter Verlag, 2005, p. 123.

John Henry Merryman, "Protection" of the Cultural "Heritage"? The American Journal of Comparative Law, Vol. 38 1990, p. 515.

Siehr K, Kunstrecht, Verlag CH Beck, 2012, S. 93.

Weidner Amalie, Kulturgüter als res extra commercium im internationalen Sachenrecht, De Gruyter Verlag, 2013, S. 46.

Beat Schönenberger, Restitution von Kulturgut, Anspruchsgrundlagen -

Restitutionshindernisse - Entwicklung, Stämpfli Verlag AG Bern - 2009, p. 73

Siehr K. The Protection of Cultural Property: the 1995 UNIDROIT Convention and the EEC Instruments of 1992/93 Compared, RDU 1998-2 / 3, p . 675.

Siehr K. , Vereinheitlichung des Mobiliarsachenrechtes in Europa, insbesondere im Hinblick auf Kulturgüter, RabelsZ (1995) S. 454, 462.

Beat Schönenberger, Restitution von Kulturgut, Anspruchsgrundlagen -

Restitutionshindernisse - Entwicklung, Stämpfli Verlag AG Bern - 2009, p. 166.

Anette Hipp , Schutz von Kulturgütern in Deutschland Walter de Gruyter Verlag, Berlin New York 2000, p. 159.

Grabitz Hilf Nettesheim, Das Recht der Europäischen Union, Art. 36 AEUV, 2015, Rdnr. 31.

Boguslavsky M.M. Cultural values in international circulation - legal aspects, Moscow -

Norma, 2015, p. 286, Carl, Güttler, Siehr, Kunstdiebstahl vor Gericht, City of Gotha v. Sotheby‘s / Cobert Finance SA, 2001, De Gruyter, S. 52.

K. Siehr, Prozesse über geschütztes Kulturgut in Deutschland, KUR, 2012/1, S. 5.

Bettina Thorn, Internationaler Kulturgüterschutz nach der Unidroit - Konvention, De Gruyter Recht Berlin, S. 194. 
Boguslavsky M.M. Cultural values in international circulation - legal aspects, Moscow Norma, 2015, p. 287.

Legislation, jurisprudence and other sources

Bulletin of the Republic of Lithuania, $2004 \mathrm{Nr}$. 135-4900.

Bulletin of the Republic of Lithuania, $2014 \mathrm{Nr}$. XII -1293 .

Bulletin of the Republic of Lithuania , $2000 \mathrm{Nr}$. 74-2262.

Bulletin of the Republic of Lithuania, $1992 \mathrm{Nr}$. 33-1014 .

Bulletin of the Republic of Lithuania , $1991 \mathrm{Nr}$. 16-415 .

Bulletin of the Republic of Lithuania , 1997 Nr . 8-139 .

Bulletin of the Republic of Lithuania, $1999 \mathrm{Nr}$. 60-1948 .

Bulletin of the Republic of Lithuania , $2012 \mathrm{Nr}$. 83-4352.

Bulletin of the Republic of Lithuania, $1995 \mathrm{Nr}$. 53-1292.

Bulletin of the Republic of Lithuania, $1996 \mathrm{Nr}$. 10-178.

Bulletin of the Republic of Lithuania, $2004 \mathrm{Nr}$. 111-4123.

Bulletin of the Republic of Lithuania, $1996 \mathrm{Nr}$. 14-352.

Bulletin of the Republic of Lithuania, $2004 \mathrm{Nr}$. 135-4900.

Bulletin of the Republic of Lithuania , $2008 \mathrm{Nr}$. 81-3183.

French Civil Code (Napoleon Code) Publisher: "Infotropic Media” (2011).

September 15, 1951. The data of the Lithuanian Special Archive of the F. SB Ap . P 12197, 1. 24.

Extract from the minutes $\mathrm{Nr}$. 41st Special Meeting at the USSR Ministry of State Security.

Resolution of the Constitutional Court of the Republic of Lithuania On the Compliance with the Constitution of the Republic of Lithuania Art. 7 h. 4 and art. 12 of the Law on International Treaties of the Republic of Lithuania, Vilnius, October 17, 1995.

Decision of the Constitutional Court of the Republic of Lithuania on 14 March 2006 , the case Nr . 17 / 02-24 / 02-06 / 03-22 / 04.

Resolution of the Constitutional Court of the Republic of Lithuania On Compliance with the Constitution of the Republic of Lithuania dated March 16, 1999 On Compliance with the Constitution of the Republic of Lithuania Art. 5 of the Law on Museums. 
Decision of the Vilnius Regional Court dated October 25, 2010 Civil case Nr . 2-39-560 / 2010.

The decision of the Vilnius District Court on February 15, 2013, civil case Nr . 2-172-450 / 2013.

Decision of the Lithuanian Court of Appeal dated November 8, 2013. Civil case Nr . 2A$1809 / 2013$.

Decision of the Supreme Court of Lithuania dated June 20, 2014. Civil case Nr. 3K-3-357 / 2014 .

Judgment of the Court of 10 December 1968. Commission of the European Communities v Italian Republic. Case 7-68.

Judgment of the Court (Second Chamber) of 30 April 2009, Fachverband der Buch- und Medienwirtschaft v LIBRO Handelsgesellschaft mbH, Case C-531/07.

Attorney-General of New Zealand v Ortiz, Case Reference [1984] AC 1; [1984] 2 WLR 809; [1983] 2 All ER 93; [1983] 2 Lloyd's Rep 265.

Government of the Islamic Republic of Iran v The Barakat Gallery Ltd, Case No: A2 I 2007/0902 / QBENF, Royal Courts of Justice Strand, London, WC2A 2LL 21/12/2007.

French Ministry of Culture v. Italian Ministry of Culture and De Contessini, Cass. 24 November 1995, n. 12166.

Winkworth v Christie, Manson \& Woods Ltd., [1950] 2 Weekly Law Reports 937 (Ch. D.)

Bescheinigung Über die Eigentumsverhältnisse an dem Gemälde Aschermittwochsmorgen von Adolph von Menzel zur Vorlage beim Bezirksgericht Vilnius, 13 September 2012.

Bescheinigung Über die Eigentumsverhältnisse an dem Gemälde Drei Marien am Grabe von Christi von Antonio Campi zur Vorlage beim Bezirksgericht Vilnius, 10 September 2012. 